\title{
Adaptability and Survivability of Different Crossbreds cattle under Commercial Dairy Farming Conditions in Chittagong area
}

\author{
Azam MA, Khan MKI* and Das A \\ Department of Genetics and Animal Breeding, Chittagong Veterinary and Animal Sciences University, \\ Khulshi, Chittagong-4225, Bangladesh.
}

[Received: July 24, Accepted: September 05, 2012]

\begin{abstract}
The present study was undertaken to investigate the adaptability and survivability of different crossbred dairy cows under commercial farming conditions in Chittagong, Bangladesh. Different cattle genotypes (Holstein $\times$ Local, Sahiwal $\times$ Local, Sahiwal $\times$ Holstein and Jersey $\times$ Local) were found in the studied farms. The percentages of Holstein $\times$ Local was $(58.94 \%)$ higher than other genotype. The survivability of Holstein $\times$ Local, Sahiwal $\times$ Local, Sahiwal $\times$ Holstein and Jersey $\times$ Local calves were 84.0 $33.90,100,97.1 \pm 5.48$ and 100 percent, respectively. The survivability of calves and cows were significantly different $(\mathrm{P}<0.05)$ among genotype. Survivability of bull-calves and heifers were similar for all the genotypes.
\end{abstract}

Key words: Genotypes, adaptability, survivability, and dairy farm.

\section{INTRODUCTION}

For meeting the demand of liquid milk in Bangladesh the inclusion of temperate breeds are increasing under farming conditions. Temperate breeds and their crosses produce more milk than tropical breeds and crossbreds but their survivability is lower than local (Zebu type), and tropical breeds and their crossbreds in tropical environment ${ }^{[1,2,3]}$.

Survivability is the capability of a system to withstand a disaster or hostile environment, without significant impairment of its normal operations. The information of adaptability and survivability and their associated factors of different purebreds and crossbreds' dairy cattle from temperate and other tropical country studies are abundant in literature ${ }^{[4,5}$, 6], however in Bangladesh this information are very limited. For the introduction of future genetic improvement programme of dairy cattle and for the sustainable of dairy production more study on survivability and adaptability of different dairy cattle breeds is essential. Therefore, the current study was addressed under the commercial dairy farming conditions of Chittagong, Bangladesh, with the following objectives (i) to know the adaptability and survivability of different crossbred dairy cows under commercial dairy farming; and (ii) to identify the factors associated with survivability and adaptability of different crossbred dairy cows.

\section{MATERIALS AND METHODS}

A questionnaire was designed to collect the relevant information of survivability and adaptability of different dairy cattle breeds under commercial dairy farming in Chittagong district of Bangladesh. During
June to November, 2011 a total of 8 commercial dairy farms were surveyed. The criteria for chosen the studied farm was: the farm should have at least 20 milking cows of mixed breeds (Local, Friesian, Sahiwal, Jersey and their crosses: Local $\times$ Friesian, Sahiwal $\times$ Local, Sahiwal $\times$ Friesian, Friesian $\times$ Local, Jersey $\times$ Local).

The criteria that are surveyed were (i) Number of total cattle in each breed of the farm; (ii) Number of calves, heifers, bull calves, bulls, milking cows and dry cows etc. according to age; (iii) Missing of animals due to sell, slaughter, death was also recorded; and (iv) Other management and rearing information such as, breeding, feeding, housing health care, vaccination, etc.

Data were collected by the researcher from the selected farms by direct visit through interviewing and direct observation. Some information was collected from farmers records (those who have records).

The age of the animals were estimated as per the dentition of the animals according to Johnson ${ }^{[7]}$. The survivability of different age groups was calculated by using the following equation and was expressed as percentage.

$$
\text { Sur }=1-\mathrm{S}-\mathrm{R}-\mathrm{D}
$$

Where, Sur $=$ Survivability.

$\mathrm{S}=$ Number of sale.

$\mathrm{R}=$ Number of replacement.

$\mathrm{D}=$ Number of death.

The collected data were edited and were calculated the mean and standard deviation of survivability and percentages of breeds, different categories of animal 
and different ages of cows under different farms by using Microsoft Excel. The differences between means of different genotypes were performed using the least significant difference test ${ }^{[8]}$ at $\mathrm{P} \leq 0.05$ and $\mathrm{P} \leq 0.01$.

\section{RESULTS AND DISCUSSION}

\section{Adaptability and survivability}

Breed composition of surveyed farm, percentages of the different genotypes of cows and the different age groups under farming condition at Chittagong area are shown in the Table 1, 2 and 3, respectively. The results showed that the herds under commercial dairying at Chittagong area consisting of different genotypes namely, Holstein-Friesian $\times$ Local, Sahiwal $\times$ Local, Sahiwal $\times$ Holstein-Friesian.

Table 1. Percentage of different genotypes under farming conditions at Chittagong area percentage was observed in both Sahiwal $\times$ Holstein and Jersey $\times$ local crosses but highest percentage was for Sahiwal $\times$ Local. In the case of cows, the higher percentage was observed for Jersey $\times$ local than other genotypes. Khan ${ }^{[3]}$ reported percentage of alive milking cows was higher in Sahiwal $\times$ Holstein and lowered in Jersey $\times$ Pabna. However, in the current study Jersey $\times$ local showed higher survival. This difference may be due to the differences of farm management.

The survivability of different categories of animal for different genotypes under farming condition at Chittagong area is shown in the Table 4. From this table 4, it can be seen that the survivability of calves were highest in both Sahiwal $\times$ Local and Jersey $\times$ Local crossbreds and lower in Friesian $\times$ Local crossbred. The survivability of heifers was similar in both Friesian $\times$ local and Sahiwal $\times$ Friesian and Sahiwal $\times$ Local and Jersey $\times$ Local genotypes, respectively. For bull-calves the survivability was higher in Sahiwal $\times$ Friesian and lower in Sahiwal $\times$

\begin{tabular}{ccc}
\hline Genotypes & Total no. of animals & Percentage of the total \\
\hline$H \times L$ & 122 & 58.94 \\
$S \times L$ & 24 & 11.59 \\
$S \times H$ & 50 & 24.16 \\
$J \times L$ & 11 & 5.31 \\
\hline
\end{tabular}

Legends: $\mathrm{H} \times \mathrm{L}=$ Holstein $\times$ Local; $\mathrm{S} \times \mathrm{L}=$ Sahiwal $\times$ Local; $\mathrm{S} \times \mathrm{F}=$ Sahiwal $\times$ Friesian and $\mathrm{J} \times \mathrm{L}=$ Jersey $\times$ Local .

The Holstein crosses were more in number than other genotypes (Table 1) because they produce higher milk than any other genotypes and are profitable for 2 to 3 lactations under farming conditions. Khan ${ }^{[3]}$ reported that the Holstein genetics is produce higher milk than other genotypes under the commercial farms in Bangladesh. Similar results were also reported in the other study ${ }^{[9]}$. From Table 2, it can be seen that the Holstein $\times$ Local crossbreds appears to have higher herd life than other crossbreds.

Table 2. Percentage of different genotypes under different age groups

Legends: $\mathrm{H} \times \mathrm{L}=$ Holstein $\times$ Local; $\mathrm{S} \times \mathrm{L}=$ Sahiwal $\times$ Local; $\mathrm{S} \times \mathrm{F}=$
Local crosses. In milking cows survivability was higher in Jersey $\times$ Local crosses and lower in Sahiwal $\times$ Friesian crosses.

Holstein $\times$ local was more adaptable under farming conditions than other genotypes but Khan ${ }^{[3]}$ reported adaptability was higher in case of Sahiwal $\times$ Friesian. From the recent study, it has been seen that the survivability of different categories of animals of different genotypes varied. In calves survivability was almost similar in both Sahiwal $\times$ Local and Jersey $\times$ Local and lowered in Friesian $\times$ Local. The survivability of heifers was higher in both Sahiwal $x$ Local and Jersey $\times$ Local genotypes. It may be due to poor conception rates, perinatal mortality, death as young stock, failure to conceive or due to abortion.

\begin{tabular}{cccccccccc}
\hline \multirow{2}{*}{ Genotypes } & \multicolumn{10}{c}{ Age group (years) of the cows } \\
\cline { 2 - 10 } & $\mathbf{3}$ & $\mathbf{4}$ & $\mathbf{5}$ & $\mathbf{6}$ & $\mathbf{7}$ & $\mathbf{8}$ & $\mathbf{9}$ & $\mathbf{1 0}$ \\
\hline $\mathrm{H} \times \mathrm{L}$ & 32.79 & 24 & 16 & 9.8 & 6.6 & 4.10 & 3.28 & 3.28 \\
$\mathrm{~S} \times \mathrm{L}$ & 33.33 & 25 & 21 & 0 & 13 & 4.20 & 4.17 & 0 \\
$\mathrm{~S} \times \mathrm{H}$ & 22.00 & 26 & 10 & 14.0 & 12 & 6.00 & 8.00 & 0 \\
$\mathrm{~J} \times \mathrm{L}$ & 18.18 & 36 & 9.1 & 18.0 & 9.1 & 0 & 9.09 & 0 \\
\hline
\end{tabular}

Sahiwal $\times$ Friesian and $\mathrm{J} \times \mathrm{L}=$ Jerse $\mathrm{x}$ Local .

From the table 3 , it was observed that percentages of alive calves were higher in Holstein cross and lowers in Sahiwal cross. In case of heifer, the percentage of alive animal was almost same in both Holstein and Sahiwal crosses. In bull calves, the similar

Wathes ${ }^{[10]}$ resulted $6.7 \%$ of animals were lost before
reaching first service at 15 months due to disease or accident and another $2.3 \%$ failed to conceive in heifers. In bull-calves survivability was higher in Sahiwal $\times$ Friesian and lowered in Sahiwal $\times$ Local. In case of milking cows the survivability was highest in Jersey $\times$ Local and lowered in Sahiwal $\times$ Friesian. 
Similar results were found in the study ${ }^{[11]}$. However, Khan ${ }^{[3]}$ and Hare ${ }^{[12]}$ reported that the Holstein and its crossbreds have lowered survivability than Pabna and Sahiwal cattle under Bangladesh farming conditions. A similar result was also obtained in the current study.

Table 3. Percentage of different categories of a live animals for different genotypes under farming condition nutrition, veterinary care, herd expansion plans, milk quota.

\section{CONCLUSION}

From the present study, it was found that farmers in Chittagong area reared cows with Holstein genetics in higher proportion than other genotypes. Holstein genetics remain longer period within the herd than

\begin{tabular}{|c|c|c|c|c|c|}
\hline \multirow{2}{*}{ Genotypes } & \multicolumn{4}{|c|}{ Types of animals } & \multirow{2}{*}{ Total percentage } \\
\hline & Calves (\%) & Bull-Calves (\%) & Heifers (\%) & Cows $(\%)$ & \\
\hline $\mathrm{H} \times \mathrm{L}$ & 32.17 & 5.88 & 19.72 & 42.21 & 100 \\
\hline $\mathrm{S} \times \mathrm{L}$ & 30 & 10.00 & 20.00 & 40.0 & 100 \\
\hline $\mathrm{S} \times \mathrm{H}$ & 30.63 & 7.21 & 17.12 & 45.05 & 100 \\
\hline $\mathrm{J} \times \mathrm{L}$ & 19.51 & 7.32 & 9.76 & 63.42 & 100 \\
\hline $\begin{array}{l}\text { The causes } \\
\text { environment } \\
\text { survivability } \\
\text { in tropical en }\end{array}$ & $\begin{array}{l}\text { ight be due } \\
\text { interactions. } \\
\text { temperate bree } \\
\text { onment was re }\end{array}$ & $\begin{array}{l}\text { the genotype } \times \\
\text { Similarly, low } \\
\text { nd their crossbreds } \\
\text { ed }^{[1,2,13]} \text {. }\end{array}$ & \multicolumn{3}{|c|}{$\begin{array}{l}\text { other. The survivability of Sahiwal } \times \text { Local and } \\
\text { Jersey } \times \text { Local crossbred calves were found to be } \\
\text { higher. In spite of the lower survivability of Friesian } \\
\times \text { Local crossbred calves farmers of Chittagong } \\
\text { region kept this crossbred more in number due to } \\
\text { higher milk production and availability of } \\
\text { replacement heifers than local and other genotypes. } \\
\text { From this study, it can be recommended that } \\
\text { Holstein } \times \text { Local crossbred could be good option for } \\
\text { future selection of cattle rearing in Bangladesh } \\
\text { perspective. The main limitations of the study were } \\
\text { small number of records per genotype that affected }\end{array}$} \\
\hline
\end{tabular}

\section{Genotypes}

\begin{tabular}{cccccc}
$\begin{array}{c}\text { Animals } \\
\text { category }\end{array}$ & $\mathbf{5} \times \mathbf{L}(\boldsymbol{\%})$ & $\mathbf{S} \times \mathbf{H}(\boldsymbol{\%})$ & $\mathbf{J} \times \mathbf{L}(\boldsymbol{\%})$ & $\begin{array}{c}\text { Level of } \\
\text { significance }\end{array}$ \\
\cline { 2 - 6 } & $\mathbf{H} \times \mathbf{L}(\boldsymbol{\%})$ & $\mathbf{S} \times \mathbf{m}$ & \\
\hline Calves & $84.0^{\mathrm{a}} \pm 3.90$ & $100^{\mathrm{b}}$ & $97.1^{\mathrm{ab}} \pm 5.48$ & $100^{\mathrm{b}}$ & $*$ \\
Heifers & $97.9 \pm 0.64$ & 100 & $97.5 \pm 7.07$ & 100 & $\mathrm{NS}$ \\
Bullcalves & $48.8 \pm 2.45$ & 50 & $56.7 \pm 9.13$ & $50 \pm 40.82$ & $\mathrm{NS}$ \\
Cow & $82.06^{\mathrm{ab}} \pm 2.191$ & $80.73^{\mathrm{ab}} \pm 14.203$ & $76.43^{\mathrm{a}} \pm 10.911$ & $97.50^{\mathrm{b}} \pm 5.586$ & $*$ \\
\hline
\end{tabular}

Legends: $\mathrm{H} \times \mathrm{L}=$ Holstein $\times$ Local; $\mathrm{S} \times \mathrm{L}=$ Sahiwal $\times$ Local; $\mathrm{S} \times \mathrm{F}=$ Sahiwal $\times$ Friesian and $\mathrm{J} \times \mathrm{L}=$ Jersey $\times$ Local. *Significant differences at $5 \% \quad(\mathrm{P}<0.05)$ level of significant; NS= Nonsignificant

the results of the study. Therefore, further studies with higher sample size are recommended.

\section{Factors affects for adaptability and survivability}

In the present study, it was found that there are several factors associated with the adaptability and survivability of the dairy cows. These are breed, farm condition, overcrowding, environmental stress, season of birth, feeding, management condition, diseases and availability of replacement heifers. Breed differences had a significant effect on survivability. Similar results and factors were also identified by other researchers [3, 9, 11, 14]. The survivability and adaptability of dairy cows was influenced by both genetic and non-genetic factors. Non-genetic factors include stall size, bedding type, degree of overcrowding, heat abatement devices,

\section{ACKNOWLEDGEMENTS}

The authors are very much grateful to the authority and staffs of department of Genetics and Animal Breeding, Chittagong Veterinary and Animal Sciences University for their valuable suggestions, encouragement and cooperation during the entire research period. The authors thanks to the farmers of the dairy farms for their friendly supports and patience provided the research information. 


\section{REFERENCES}

1. McDowell RE (1985). Crossbreeding in tropical areas with emphasis on milk,health and fitness. J. Dairy Sci. 68: 2418-2435.

2. Cunningham EP and Syrstad O (1987). Crossbreeding Bos indicus and Bos Taurus for milk production in the tropics. FAO Anim. Healt. Prod. Paper 68, Rome, Italy.

3. Khan MKI (2009). Developments of model for the genetic improvement of dairy cattle under cooperative dairying conditions in Bangladesh. $\mathrm{PhD}$ thesis, Massey University, New Zealand. http://muir.massey.ac.nz/bitstream/10179/1378/1/ 02_whole.pdf.

4. Rege JEO (1998). Utilization of exotic germplasm for milk production in the tropics. Proc $6^{\text {th }}$ World Congr. Genet. Appl. Livest. Prod. Armidale, Australia 25: 193-200.

5. Kahi AK, Nitter G, Thorpe $\mathrm{W}$ and Gall CF (2000). Crossbreeding for dairy production in the low land tropics of Kenya: 11. Reproduction performance of alternative crossbreeding strategies. Livest. Prod. Sci. 63: 55-63.

6. Menjo DK, Bebe BO, Okeyo AM and Ojango JMK (2009). Survival of Holstein-Friesian heifers on commercial dairy farms in Kenya Applied Animal Husbandry \& Rural Development 2009, Volume 2 CSouth African Society for Animal Science Peer reviewed paper: 10th World Conf. Anim. Prod. 14.

7. Johnson RF (1999). The Stockman's Handbook by Ensminger, 2nd ed., page 539.
8. Steel RGD, Torrie JH and Dickey DA (1997). Principles and procedure of statistics-A biometrical approach. McGraw- Hill Co.,Inc. NY and London Pp: 139-177.

9. Das A, Das Gupta M, Khan MKI and Miah G (2011). Effect on non-genetic factor on the productive and reproductive traits of Freisian crossbred dairy cows. Wayamba J. Anim. Sci. No. 1297506172. Pp: 62-64.

10. Wathes DC, Brickell JS, Bourne NE, Swalia A and Cheng Z (2008). Factors influencing heifer survival and fertility on commercial dairy farms. Animal, 2: 8, Pp: 1135-1143 \& The Animal Consortium 2008.

11. Khan MKI, Miah G, Kuque KS, Khatun MJ and Das A (2011). Economic and genetic evaluations of different dairy cattle breeds under rural conditions in Bangladesh. Livest. Res. Rural Devel., 24 (01) : http://www.lrrd24/1/khan24020

12. Hare E, Norman HD and Wright JR (2006). Survival Rates and Productive Herd Life of Dairy Cattle in the United States. J. Dairy Sci. 89: 3713-3720.

13. Nieuwhof GJ, Norman ND and Dickinson FN (1989). Phenotypic trends in herdlife of dairy cows in the United States. J. Dairy Sci. 72: 726736.

14. Mondal SC, Alam MM, Rashid MM, Ali MY and Hossain MM (2005). Comparative study on the productive and reproductive performance of different dairy genotypes reared in Bangladesh agricultural university dairy farm. Pakistan J. Nutr. 4(4): 222-225. 